\title{
Metal Concentration in Fresh Water Fish Organs
}

\author{
Krishnappa Venkatesha Raju, Rayasamudra Kalegowda Somashekar, \\ Konehally Lakshmaiah Prakash \\ Department of Environmental Science, Bangalore University, Bangalore, India \\ Email: environ.vrk@gmail.com
}

Received April 30, 2013; revised May 30, 2013; accepted June 7, 2013

Copyright (C) 2013 Krishnappa Venkatesha Raju et al. This is an open access article distributed under the Creative Commons Attribution License, which permits unrestricted use, distribution, and reproduction in any medium, provided the original work is properly cited.

\begin{abstract}
This study was conducted during March to May of 2010 dry season, giving prime thrust to determine the metal concentrations in commercial fish species of Catla catla and Labeo rohita, collected from various points along the river Cauvery. The liver, gill and muscle tissues of fish were analyzed for $\mathrm{Fe}, \mathrm{Pb}, \mathrm{Zn}, \mathrm{Ni}, \mathrm{Mn}, \mathrm{Cu}, \mathrm{Cr}$ and $\mathrm{Cd}$ using Atomic Absorption Spectrophotometry (AAS-model: 6300). The Catla catla has shown more accumulation potency for all the metals than Labeo rohita. The liver in both fish species has better accretion capacity compared to gill and muscle and the same was noticed by bioaccumulation factor. The results of bioaccumulation factor were in the order of $\mathrm{Ni}>\mathrm{Zn}>$ $\mathrm{Cu}>\mathrm{Mn}>\mathrm{Fe}>\mathrm{Cr}>\mathrm{Pb}>\mathrm{Cd}$. Elevated trend was noticed among the essential metals and decreased trend among the nonessential metals were observed in both fish species.
\end{abstract}

Keywords: Cauvery; Heavy Metal; Fish; Cauvery; Bioaccumulation

\section{Introduction}

Aquatic organisms have the ability to accumulate heavy metals from water column, suspended and bed sediments. Therefore, accumulation of heavy metals in aquatic organisms can pose a long lasting effect on biogeochemical cycling in the river ecosystem [1,2]. The accumulation of toxic heavy metals in the tissues of aquatic biota to hazardous levels has becomes a problem of increasing public health concern to both animals and humans. Excessive metal concentration in surface water could lead to health hazards in man, either through drinking of water and/or consumption of fish [3-6].

Among aquatic animals, fishes are widely used to evaluate the health of aquatic ecosystems because pollutants build up in the food chain and are responsible for adverse effects and consequent death $[7,8]$. In this study, the concentration of metals in fish (Catla catla and Labeo rohita) organs (liver gill and muscle) were used to calculate Bioaccumulation Factor (BAF).

\section{Methodology}

\subsection{Study Area}

In the present investigation river Cauvery of Karnataka stretch was chosen as study area (Figure 1). Cauvery is one of the principal river systems in Southern India, takes birth at Talacauvery (Kodagu) and ends by merges with Bangala kolli in Tamilnadu after traversing of around $800 \mathrm{~km}$.

\subsection{Monitoring Stations}

Eight numbers of Monitoring stations, three from upstream and five from downstream to Krishnarajasagara dam were selected based on human interference, availability of fish and human consumption. The sampling stations (Figure 1) are described as fallows.

Monitoring station 1 (V1): This station is situated in Kushalnagara, $18 \mathrm{~km}$ from Mercara city of Coorg district. This place attracts lakhs of tourists during summer because of prevailing cold climate. The Tibatian refugee colony is located $7 \mathrm{~km}$ away from this station nearby place called Bayalukuppe. The river receives perceptible amount of domestic sewage at this point.

Monitoring station 2 (V2): This point is located near Rameshwara temple of Ramanathapura town, where the State Fisheries department is rearing around 18 varieties of fishes. Besides domestic activities, ash dropping is a part of ritual practice in this station.

Monitoring station 3 (V3): This station is located near railway bridge of Hampapura village. Here water is 


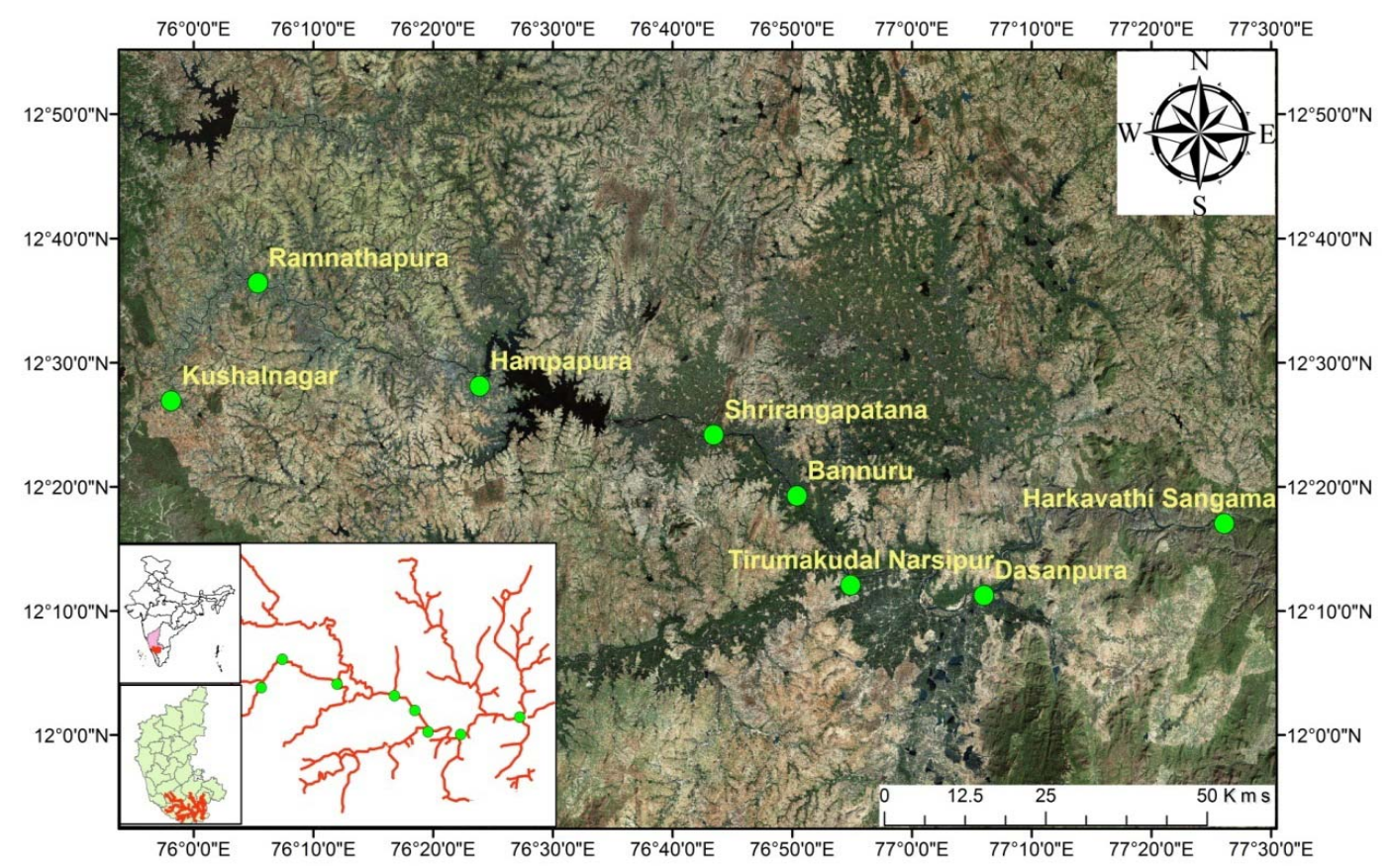

Figure 1. Showing study area.

abstracted to Krishnaraja Nagar and Krishna raja pete of Mysore district for drinking purpose. The flow rate is almost nil because of back flow triggered by Krishnaraja Sagar dam.

Monitoring station 4 (V4): It is situated $2 \mathrm{~km}$ down from Nimishambha temple of Srirangapatna known as Melapura in Mandya district, where the tributary Lokapavani merges with Cauvery. Srirangapatna, city of historic, religious, and cultural hub located around $13 \mathrm{~km}$ from Mysore. Here river is extensively used for bathing, washing, Boating and fishing. Immersion of ash is regularly witnessed.

Monitoring station 5 (V5): This point is located at Bannur bridge of Mysore District. The agricultural land, grazing field and cremation ground contribute considerable sum of pollutants into river Cauvery.

Monitoring station 6 (V6): This station is situated 1 km down from Cauvery-Kabini Sangama near Tirumakundalu Narasipura of Mysore district. Kabini River carries industrial wastes from Nanjangud industrial area to the Cauvery. Intensive sand dredging activity is in practice especially during summer. Low flow rate and nutriaent rich sediment allow luxuriant growth macrophytes.

Monitoring station 7 (V7): It is situated at Harle village, $3 \mathrm{~km}$ from Kollegala town. Upstream to this point tributary Suvarnavathy joins Cauvery. Extensive sand mining is practiced almost throughout the year, besides agriculture and fishing activities. Water abstraction and Sewage intrusion from town are two other major anthropogenic interferences practiced with river at greater extent.
Monitoring station 8 (V8): It is located at Kanakapura Sangama nearly about $36 \mathrm{~km}$ from Kanakapura town, Ramanagara district, Arkavathi river confluence Cauvery at this point. Among the tributaries of river Cauvery, Arkavathi is richly contaminated with industrial and domestic sewages but the flow is restricted in summer. It is a recreational and weekend picnic spot for Bangaloreans.

\subsection{Sampling, Preservation and Preparation}

Fish: Fish samples of two different species (Catla catla and Labeo rohita) weighing around $750 \pm 100 \mathrm{~g}$ were captured during March, April and May of 2010 dry season. The samples at frozen condition were transported to the laboratory on the same day and stored until dissecttion.

Prior to sample preparation fishes were thoroughly rinsed with distilled water to remove excess mucus coating, adhered particles and other adsorbed metals. Fishes were dissected to separate organs viz. liver gill and muscle according to FAO method [9]. After dissection, all the tissue samples were separately oven-dried at $105^{\circ} \mathrm{C} \pm$ $20^{\circ} \mathrm{C}$ and cooled to constant weight in room temperature.

Water: water samples were collected separately in $100 \mathrm{ml}$ polythene bottles prewashed with acidified water, deionised water and $2 \mathrm{ml}$ of nitric acid was added as preservative. All the water samples were stored in insulated cooler containing ice and brought on the same day to the laboratory and maintained at $4^{\circ} \mathrm{C} \pm 2^{\circ} \mathrm{C}$ until processing and analysis was over as suggested in [10]. 


\subsection{Microwave Digestion}

Fish: $1 \mathrm{~g}$ dry weight of the discrete regions (organ) of sample were introduced in to Teflon reaction vessel and $5 \mathrm{~mL}$ of $65 \%$ Nitric acid was added, the vessel was inserted into microwave chamber and subjected for digestion program as follows

Step-I: 5 minute at $20 \%$ power $(240 \mathrm{~W}) ; 1$ minute at $30 \%$ power (360 W); 5 minutes at $25 \%$ power (300 W), cooled and the digester was reopened.

Step-II: $1 \mathrm{~mL}$ of $30 \%$ Hydrogen peroxide was added and set to $25 \%$ power 3 minutes, $50 \%$ power $(600 \mathrm{~W}$ ) for 3 minutes, cooled and the digester was reopened.

Step-III: $1 \mathrm{~mL}$ of (20\%) Perchloric acid was added and power set to $50 \%(600 \mathrm{~W})$ for 2 minutes, cooled and the digester was reopened.

The resulted sample was cooled and diluted to $100 \mathrm{ml}$ using deionised water.

After dilution $\mathrm{Fe}, \mathrm{Pb}, \mathrm{Zn}, \mathrm{Mn}, \mathrm{Ni}, \mathrm{Cu}, \mathrm{Cr}$, $\mathrm{Co}$ and $\mathrm{Cd}$ contents of the tissues were measured on a Shimatzu
AAS-6300, atomic absorption spectrophotometer. The sample whose metal concentration was below the detection limit in flame furnace (in ppm) was subjected to graphite furnace (in ppb) analysis.

Water: $10 \mathrm{ml}$ of water samples were added to Teflon tubes/ reference vessel fallowed by $1 \mathrm{ml}$ of Conc. $\mathrm{HNO}_{3}$, the vessel was closed with valve and tightened. They were inserted into a single safety shield carousel and, into the microwave chamber. The system was pre-programmed using the Ethos D control terminal (equipped with software) for 5 min of microwave digestion at 250 $\mathrm{W}$ power and left for automatic ventilation for $2 \mathrm{~min}$. The digested solution was cooled and made up to 100 $\mathrm{mL}$ with Milli-Q distilled water and stored in special containers ready for analysis.

\section{Results and Discussion}

The metal concentration in river water, fish and bioaccumulation factor for fish tissues are given in Table 1.

Table 1. The heavy metal concentrations in fish $\left(\mu \mathrm{g} \cdot \mathrm{g}^{-1} \mathrm{dry} \mathrm{wt}.\right)$, river water $\left(\mu \mathrm{g} \cdot \mathrm{l}^{-1}\right)$ with standard error and their bioaccumulation factor (BAF).

\begin{tabular}{|c|c|c|c|c|c|c|c|c|c|c|}
\hline \multirow{2}{*}{ Loc. } & \multirow{2}{*}{ Metal } & \multirow{2}{*}{ Water } & \multicolumn{4}{|c|}{ Catla Catla } & \multicolumn{2}{|c|}{ Labeo Rohita } & \multirow[b]{2}{*}{ Muscle } & \multirow[b]{2}{*}{ BAF } \\
\hline & & & Gills & Liver & Mussel & BAF & Gills & Liver & & \\
\hline \multirow{8}{*}{ V1 } & $\mathrm{Fe}$ & $54 \pm 2.89$ & $7.35 \pm 0.49$ & $8.25 \pm 0.52$ & $6.35 \pm 0.37$ & 0.004 & $6.25 \pm 0.39$ & $6.96 \pm 0.39$ & $5.81 \pm 0.31$ & 0.004 \\
\hline & $\mathrm{Pb}$ & $0.14 \pm 0.03$ & $\mathrm{BDL}$ & BDL & BDL & 0.000 & $\mathrm{BDL}$ & $\mathrm{BDL}$ & $\mathrm{BDL}$ & 0.000 \\
\hline & $\mathrm{Zn}$ & $7.3 \pm 1.32$ & $2.35 \pm 0.16$ & $4.22 \pm 0.26$ & $1.31 \pm 0.08$ & 0.070 & $2.55 \pm 0.16$ & $3.04 \pm 0.17$ & $1.30 \pm 0.07$ & 0.055 \\
\hline & $\mathrm{Ni}$ & $0.19 \pm 0.04$ & $0.05 \pm 0.00$ & $0.21 \pm 0.01$ & BDL & 0.078 & $0.05 \pm 0.00$ & $0.15 \pm 0.01$ & BDL & 0.056 \\
\hline & $\mathrm{Cr}$ & $0.76 \pm 0.09$ & BDL & BDL & BDL & 0.000 & BDL & BDL & BDL & 0.000 \\
\hline & $\mathrm{Mn}$ & $3.2 \pm 0.14$ & $0.10 \pm 0.01$ & $0.14 \pm 0.01$ & $0.10 \pm 0.01$ & 0.014 & $0.02 \pm 0.00$ & $0.10 \pm 0.01$ & BDL & 0.006 \\
\hline & $\mathrm{Cu}$ & $0.26 \pm 0.05$ & $0.05 \pm 0.00$ & $0.16 \pm 0.01$ & BDL & 0.061 & $0.04 \pm 0.00$ & $0.12 \pm 0.01$ & BDL & 0.045 \\
\hline & $\mathrm{Cd}$ & $0.04 \pm 0.02$ & BDL & BDL & BDL & 0.000 & BDL & $\mathrm{BDL}$ & BDL & 0.000 \\
\hline \multirow{8}{*}{ V2 } & $\mathrm{Fe}$ & $8.4 \pm 2.31$ & $5.81 \pm 0.39$ & $6.10 \pm 0.38$ & $5.35 \pm 0.31$ & 0.001 & $6.24 \pm 0.39$ & $7.15 \pm 0.40$ & $4.93 \pm 0.26$ & 0.001 \\
\hline & $\mathrm{Pb}$ & $0.12 \pm 0.02$ & BDL & BDL & BDL & 0.000 & BDL & BDL & BDL & 0.027 \\
\hline & $\mathrm{Zn}$ & $2.9 \pm 0.85$ & $3.02 \pm 0.20$ & $3.85 \pm 0.24$ & $2.52 \pm 0.15$ & 0.187 & $3.18 \pm 0.20$ & $3.75 \pm 0.21$ & $2.44 \pm 0.13$ & 0.182 \\
\hline & $\mathrm{Ni}$ & $0.40 \pm 0.10$ & $0.04 \pm 0.00$ & $0.12 \pm 0.01$ & BDL & 0.012 & $0.07 \pm 0.00$ & $0.15 \pm 0.01$ & $\mathrm{BDL}$ & 0.008 \\
\hline & $\mathrm{Cr}$ & $0.20 \pm 0.03$ & BDL & $0.15 \pm 0.01$ & BDL & 0.018 & BDL & BDL & BDL & 0.000 \\
\hline & Mn & $6.6 \pm 0.33$ & $0.20 \pm 0.01$ & $0.28 \pm 0.02$ & $0.11 \pm 0.01$ & 0.009 & $0.16 \pm 0.01$ & $0.17 \pm 0.01$ & $0.12 \pm 0.01$ & 0.007 \\
\hline & $\mathrm{Cu}$ & $0.13 \pm 0.05$ & $0.20 \pm 0.01$ & $0.26 \pm 0.02$ & $0.15 \pm 0.01$ & 0.072 & $0.18 \pm 0.01$ & $0.18 \pm 0.01$ & $0.15 \pm 0.01$ & 0.058 \\
\hline & $\mathrm{Cd}$ & $0.03 \pm 0.01$ & BDL & BDL & BDL & 0.000 & BDL & $\mathrm{BDL}$ & BDL & 0.000 \\
\hline \multirow{8}{*}{ V3 } & $\mathrm{Fe}$ & $99.4 \pm 5.21$ & $9.25 \pm 0.62$ & $12.35 \pm 0.77$ & $8.14 \pm 0.48$ & 0.001 & $8.13 \pm 0.51$ & $8.55 \pm 0.48$ & $7.32 \pm 0.39$ & 0.000 \\
\hline & $\mathrm{Pb}$ & $0.34 \pm 0.10$ & BDL & BDL & BDL & 0.000 & BDL & $\mathrm{BDL}$ & BDL & 0.000 \\
\hline & $\mathrm{Zn}$ & $16.2 \pm 2.65$ & $4.86 \pm 0.32$ & $5.62 \pm 0.35$ & $3.37 \pm 0.20$ & 0.036 & $4.35 \pm 0.27$ & $5.21 \pm 0.29$ & $3.14 \pm 0.17$ & 0.033 \\
\hline & $\mathrm{Ni}$ & $0.38 \pm 0.04$ & $0.19 \pm 0.01$ & $0.20 \pm 0.01$ & $0.14 \pm 0.01$ & 0.008 & $0.10 \pm 0.01$ & $0.11 \pm 0.01$ & $0.10 \pm 0.01$ & 0.003 \\
\hline & $\mathrm{Cr}$ & $0.78 \pm 0.09$ & BDL & $0.13 \pm 0.01$ & BDL & 0.005 & BDL & BDL & BDL & 0.000 \\
\hline & Mn & $9.8 \pm 0.74$ & $0.34 \pm 0.02$ & $0.41 \pm 0.03$ & $0.33 \pm 0.02$ & 0.004 & $0.25 \pm 0.02$ & $0.28 \pm 0.02$ & $0.20 \pm 0.01$ & 0.003 \\
\hline & $\mathrm{Cu}$ & $0.59 \pm 0.09$ & $0.40 \pm 0.03$ & $0.47 \pm 0.03$ & $0.33 \pm 0.02$ & 0.061 & $0.30 \pm 0.02$ & $0.36 \pm 0.02$ & $0.24 \pm 0.01$ & 0.045 \\
\hline & $\mathrm{Cd}$ & $0.06 \pm 0.03$ & BDL & BDL & BDL & 0.000 & BDL & BDL & BDL & 0.000 \\
\hline
\end{tabular}


Continued

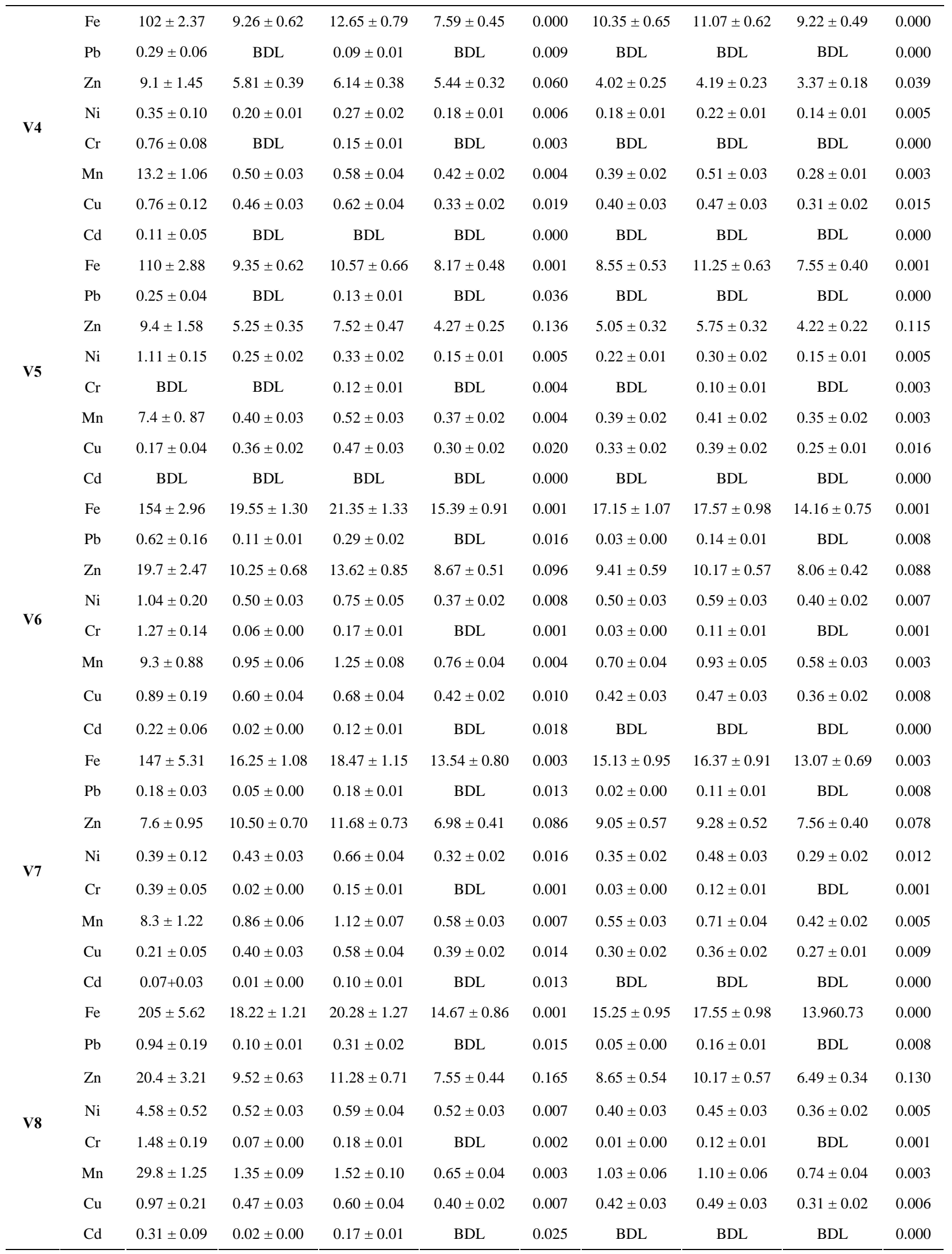


The concentration of metals in water column between eight sampling sites not differs significantly and showed higher concentration in comparison with fish tissues.

The concentration of all the analyzed metals in both the species of fish tissues were observed to be high in downstream stations. It could be due to dumped agricultural and industrial wastes to downstream region of the river through streams and tributaries at significant level. In addition to this Sand dredging activities makes metal to available for fish and other aquatic life consumption.

The liver tissue of both the species contained higher accumulation fallowed by gills and muscle tissues. The higher levels of metals in liver relative to gills and muscle may be attributed to the affinity or strong coordination of metallothionein protein with the metals [11,12].

The concentrations of metals in fish samples indicated that Catla catla seemed to be good accumulator fish species than Labeo rohita. These observations are might be due to different fish feeding habit and habitat. These results agree with that obtained by Karadede-Akin, et al. [13] and Rauf, et al. [14] in the river Tigris and Ravi respectively.

Among the analysed essential metals (Fe, Zn, Mn, Ni, $\mathrm{Cu}$ and $\mathrm{Cr}$ ) Fe was found highest and $\mathrm{Cr}$ was least. Liver tissue of Catla catla of downstream stations were exhibited very negligible concentrations of non essential metals ( $\mathrm{Pb}$ and $\mathrm{Cd}$ ) and BDL was noticed in muscle. In other hand Labio rohita has not showed $\mathrm{Pb}$ and $\mathrm{Cd}$ accumulation.

The bioaccumulation factor (BAF) (Table 1) of heavy metals in different samples revealed increase trend from upstream to downstream, which can be explained on the basis of inflow of anthropogenic pollutants to the Cauvery in the downstream stretch. Also, the BAF values showed elevated trend in case of essential trace metals than nonessential metals.

BAF for fishes is in the sequence of $\mathrm{Ni}>\mathrm{Zn}>\mathrm{Cu}>$ $\mathrm{Mn}>\mathrm{Fe}>\mathrm{Cr}>\mathrm{Pb}>\mathrm{Cd}$. The BAF values for different heavy metals from water to fishes or sediment to fishes are a key component of human exposure to the metal through food chain. The lowest BAF value in this study is for $\mathrm{Cd}$; one of the likely reasons is being that it is more mobile in the natural environment than the other metals.

\section{Conclusion}

From the present study, it concluded that the metal concentrations were lower in fish tissues of both the species than water column. Fish samples of downstream stations have combatively accumulated more metals than upstream stations as metals concentration varies in water of the river stretch. This suggested that metal accumulation in fish bodies appears as site specific, corresponding with the metallic toxicity of the two aquatic components, viz., water sediment and planktons.

\section{REFERENCES}

[1] T. H. Goodwin, A. R. Young, M. G. R. Holmes, G. H. Old, N. Hewitt, G. J. L. Leeks, J. C. Packman and B. P. G. Smith, "The Temporal and Spatial Variability of Sediment Transport and Yields within the Bradford Beck Catchment, West Yorkshire," Science Total Environment, Vol. 14, No. 16, 2003, pp. 475-494. doi:10.1016/S0048-9697(03)00069-X

[2] T. G. More, R. A. Rajput and N. N. Bandela, "Impact of Heavy Metals on DNA Content in the Whole Body of Freshwater Bivalve, Lamelleiden marginalis," Environmental pollution and Research, Vol. 22, 2003, pp. 605616.

[3] B. J. Mathis and T. F. Cummings, "Selected Metals in Sediments, Water and Biota in the Illinois River," Journal (Water Pollution and Control Federation), Vol. 48, No. 7, 1973, pp. 1573-1583.

[4] F. Kargin, "Metal Concentration in Tissues of The Fresh Water Fish Capoeta barroisi from the Seyhan River (Turkey)," Bulletin Environmental Contamination and Toxicology, Vol. 60, No. 5, 1998, pp. 822-828.

doi:10.1007/s001289900701

[5] M. Kalay, O. Ay and M. Canh, "Heavy Metal Concentration in Fish Tissues from the Northeast Mediterranean Sea,” Bulletin Environmental Contamination and Toxicology, Vol. 63, No. 5, 1999, pp. 671-673. doi:10.1007/s001289901033

[6] W. Ashraf, “Accumulation of Heavy Metals in Kidney and Heart Tissues of Epinephelus microdon Fish from the Arabian Gulf," Environmental Monitoring and Assessment, Vol. 101, No. 1-3, 2001, pp. 311-316. doi:10.1007/s10661-005-0298-4

[7] F. E. Olaifa, A. K. Olaifa, A. A. Adelaja and A. G. Owolabi, "Heavy Metal Contamination of Clarias gariepinus (African Cat Fish) from a Lake and Fish Farm in Ibadan, Nigeria,” African Journal of Biomedical Research, Vol. 7, No. 3, 2004, pp.145-148.

[8] R. Vinodhini and M. Narayanan, "Bioaccumulation of Heavy Metals in Organs of Fresh Water Fish Cyprinus carpio (Common carp)," International Journal of Environmental Science and Technology, Vol. 5, No. 2, 2008, pp. 179-182.

[9] B. Dybem, "Field Sampling and Preparation of Subsamples of Aquatic Organisms for Analysis of Metals and Organochlorides," Fisher Technology, Vol. 212, 1983, pp. $1-13$.

[10] APHA, "Standard Methods for the Examination of Water and Waste Water,” American Public Health Association, Washington DC, 2005.

[11] A. G. Heath, "Water Pollution and Fish Physiology," CRC Press, Inc., Boca Rotan, 1987.

[12] A. Ikem, N. O. Egiebor and K. Nyavor, “Trace Elements in Water, Fish and Sediments from Tuskegee Lake, Southeastern USA,” Water Air and Soil Pollution, Vol. 149, No. 1-4, 2003, pp. 51-75. doi:10.1023/A:1025694315763 
[13] H. Karadede-Akin and E. Unlu, "Heavy Metal Concentrations in Water, Sediments, Fish and Some Benthic Organisms from Tigris River, Turkey," Environmental Monitoring and Assessment, Vol. 131, No. 1, 2007, pp. 323337. doi:10.1007/s10661-006-9478-0
[14] A. Rauf, M. Javed and M. Ubaidullah, "Heavy Metal Levels in Three Major Carps (Catla catla, Labeo rohita and Cirrhina mrigala) from the River Ravi, Pakistan,” Pakistan Veterinary Journal, Vol. 29, No. 1, 2008, pp. 24-26. 